Forum: On Azfar Moin's The Millennial Sovereign

2.

\title{
OF SOVEREIGNS, SACRED KINGS, AND POLEMICS
}

\author{
HUSSEIN FANCY
}

\begin{abstract}
In its emphasis on ritual and sacred kingship, Azfar Moin's The Millennial Sovereign bears the imprint of anthropological theory, but Moin addresses this inheritance only obliquely. This essay seeks to draw out that tradition and to place theories of sovereignty and sacred kingship in their intellectual and historical context. Ultimately, it questions the value of these theories to the study of political authority.
\end{abstract}

Keywords: sovereignty, sacred kingship, anthropology, political theology, polemic, Mediterranean Sea, medieval, religion, politics

Azfar Moin's The Millennial Sovereign is a marvelous and beautiful study of sacred kingship in Mughal India and Safavid Iran. ${ }^{1}$ There is much to admire in this book. It ranges widely across time and space - three centuries, spanning Iran, Central Asia, and India. It examines a wide array of subjects - astrology, lore, court rituals, dress, paintings, architecture, cults, and bodies. It contains a wild cast of characters - astrologers, diviners, saints, poets, and kings. And who cannot love the portrait of Akbar, which cuts through so much polemical nonsense? Few could pull off this kind of scholarship. It is a book well deserving of a wide readership.

The Millennial Sovereign proposes to overturn the prevailing narrative of Islamic political authority. Moin challenges the view that Islamic rulers were essentially secular figures, kings who sought legitimacy from the standard-bearers of orthodoxy, the 'ulamā'. The script of Islamic sovereignty, Moin argues, was not written at court but rather in the diverse imaginations of the wider world. It reflected a forgotten episteme that emerged at the historical intersection of Sufi sainthood, Mongol universalism, millenarianism, and astrology. Rather than in rigid doctrines and texts, Islamic kingship was located in supple rituals and bodily performances. This shift of perspective explains the strangeness around kings, the heretical and antinomian practices - the seals, the utterances, the breathing upon water-which were once dismissed as alien intrusions. Significantly, for Moin, these rituals should be read as neither political calculation nor blind superstition. Political authority was neither simply a matter of self-presentment nor collective neurosis. ${ }^{2}$ Instead, sacred kingship was fundamentally numinous and

1. A. Azfar Moin, The Millennial Sovereign: Sacred Kingship and Sainthood in Islam (New York: Columbia University Press, 2012).

2. Borrowing a phrase from Clifford Geertz, "Centers, Kings, and Charisma: Symbolics of Power," in Local Knowledge: Further Essays in Interpretive Anthropology (New York: Basic Books, 1983), 122. 
exceptional: "Sacred in the classic anthropological sense of the word, it was both a space and a state of exception that was above the constraints of the ordinary." ${ }^{3}$ But if kings were sacred, then their sovereignty was not absolute. Echoing Peter Brown's The Cult of Saints, Moin contends that kings were bound in a "mimetic embrace" with saints, enveloped by an aura of sanctity. ${ }^{4}$ Kingship was a public performance-a "charade" or "myth," with the scare quotes included-governed by a set of unspoken rules. ${ }^{5}$ Ritual was the forge that transformed the individual into an enduring, if combustible, institution:

The way to win was not, as is normally assumed, to impose one's "ideology" on the masses but rather the other way around: to pour oneself into the mythic molds of the hero, the saint, and the messiah-molds shaped by collective imagination and social memory. Reputations of kings and saints were made or ruined depending on how their engagement with the sacred was enacted, publicized, and collectively remembered. ${ }^{6}$

With this bold revision, Moin has also invigorated a field of research. $\mathrm{He}$ draws together the work of Sanjay Subrahmanyam and Vincent Cornell, who have examined early modern millenarianism across Eurasia, with the work of Shahzad Bashir and Kathryn Babayan, who have explored the origins of this mood in earlier centuries. ${ }^{7}$ Moin's synthesis has already paved the way for new research on the development of Islamic kingship in Indo-Iranian societies. ${ }^{8}$ At a theoretical and methodological level, The Millennial Sovereign should and will also provoke new debates about the relationship between politics and religion in the premodern Islamic world. ${ }^{9}$ It joins others in offering a provocative answer to the question: what is Islam?

As a scholar of medieval Iberia and North Africa, I can only speak on this subject from a distance, but I will suggest that there are important and meaningful connections between the Mediterranean context and the Indo-Iranian one. In what follows, however, I want to attend most closely to questions of theory and method. In its vocabulary and exposition-above all, in its emphasis on ritual and sacred kingship-The Millennial Sovereign bears the imprint of anthropological theory.

3. Moin, The Millennial Sovereign, 226.

4. Ibid., 5 .

5. Ibid., 16.

6. Ibid., 54.

7. Sanjay Subrahmanyam, "Connected Histories: Notes Towards a Reconfiguration of Early Modern Eurasia," Modern Asian Studies 31, no. 3 (1997), 735-762; Cornell H. Fleischer, "The Lawgiver as Messiah: The Making of the Imperial Image in the Reign of Süleymân," in Soliman le magnifique et son temps, ed. Gilles Veinstein (Paris: La Documentation Française, 1992), 159-177; Shahzad Bashir, Messianic Hopes and Mystical Visions: The Nürbakhshīya between Medieval and Modern Islam (Columbia: University of South Carolina Press, 2003), 29-75; and Kathryn Babayan, Mystics, Monarchs, and Messiahs: Cultural Landscapes of Early Modern Iran (Cambridge, MA: Harvard University Press, 2002).

8. For instance, Matthew Melvin-Koushki, "Astrology, Letterism, Geomancy: The OccultScientific Methods of Post-Mongol Islamicate Imperialism," Medieval History Journal 19, no. 1 (2016), 142-150; Ilker Evrim Binbaş, Intellectual Networks in Timurid Iran: Sharaf al-Dīn 'Al̄̄ Yazdī and the Islamicate Republic of Letters (Cambridge, UK: Cambridge University Press, 2016); and Jonathan Brack, "Mediating Sacred Kingship: Conversion and Sovereignty in Mongol Iran," PhD dissertation, University of Michigan, 2016. I am indebted to Jonathan Brack for guiding me to and through the literature above.

9. See, for instance, Alan Strathern, "Drawing the Veil of Sovereignty: Early Modern Islamic Empires and Understanding Sacred Kingship," History and Theory 53, no. 1 (2014), 79-93. 
Nevertheless, Moin addresses this inheritance only obliquely. Marc Bloch, Ernst Kantorowicz, E. E. Evans-Pritchard, and Clifford Geertz make brief appearances in the notes. My hope here is to draw out that tradition and to place these theories about sovereignty and sacred kingship in their intellectual and historical context. If debates about the relationship between politics and religion are returning to the center of Islamic studies, then perhaps it bears asking whether this inheritance is still welcome, whether these theories illuminate more than they obscure.

Although Moin uses the terms "sovereignty" and "sacred kingship" interchangeably, in their origin they meant something rather opposed. Although medieval European kings did indeed refer to themselves as sovereigns (sobirans, souverains, and so on), a coherent theory of sovereignty properly belongs to the late-sixteenth-century French Catholic jurist, Jean Bodin. ${ }^{10}$ Bodin argued that kings had a divine right to sovereignty, by which he meant absolute authority in all matters of civil law: "Majesty or sovereignty is the most high, absolute, and perpetual power over the citizens and subjects in a Commonwealth, which the Latins call Majestas." 11 A true sovereign was accountable only to God. In his own time, in the context of the Wars of Religion and more particularly, the St. Bartholomew's Day massacre, Bodin saw an urgent need to define sovereignty precisely because it was absent. Grounded in the secular power to make law, his sovereign was individual and decisive. His sovereign was unimpeded by the church, nobility, or the people. Thus, Bodin not only understood sovereignty on very different terms than does Moin but also meant it as something prescriptive rather than descriptive. ${ }^{12} \mathrm{He}$ sought to define sovereignty precisely to overcome the practical and conceptual limits of early modern authority, to break free from the very entanglements that Moin embraces.

If at the outset the theory of sovereignty was proleptic, then the theory of sacred kingship was nostalgic..$^{13}$ Sir James Frazer's The Golden Bough, a massive and comparative study of mythology and religion, focused in particular on sacred kingship as an idea "savor[ed] of a barbarous age." ${ }^{14}$ Frazer began his journey at the Grove of Nemi, where pre-Roman priest-kings were said to have been ritually murdered by their successors. In pursuit of an explanation of this regicide, Frazer offered two universal hypotheses. First, he argued that the body of a king is equivalent to the body politic. The health of one depended on the other. Thus, when a king aged or grew ill, he threatened the body politic. He had to be killed. Second,

10. Jean Bodin, Les Six Livres de la République (Paris: Du Puys, 1576).

11. Ibid., I:8.

12. This point was made by Jonathan Sheehan during his comments at a panel on the The Millennial Sovereign at the AHA in New York in 2015. I am grateful to him for sharing a printed copy of his remarks with me.

13. For a useful guide to the question of sacred kingship, see G. Feeley-Harnik, "Issues in Divine Kingship," Annual Review of Anthropology 14, no. 1 (1985), 273-313.

14. James George Frazer, The Golden Bough: A Study in Comparative Religion (London: Macmillan, 1890), I, 10, as cited in Feeley-Harnik, "Issues in Divine Kingship," 273. The second edition, published in three volumes in 1900, was retitled The Golden Bough: A Study in Magic and Religion. The third edition, published in 1913, was expanded to twelve volumes. The tri-functional hypothesis of Georges Dumézil to explain sovereignty in Proto-Indo-European societies is worth mentioning in this context as well. See his Mitra-Varuna: Essai sur deux représentations indo-européennes de la Souveraineté (Paris: Presses universitaires de France, 1940). 
he proposed that kings absorbed and expelled evil from their communities. Rituals, including regicide, ultimately served to purify kings, to mark them as exceptional, superior, and sacred individuals. It would be difficult to overstate the influence of The Golden Bough. It captured the imagination of Yeats and Joyce as well as Cassirer and Durkheim. And most significantly for this discussion, it shaped an emerging anthropology of religion.

Whereas Frazer had examined principally ancient myth, the anthropologists influenced by him turned to the living examples of sacred kings that they encountered among "the primitive peoples" under colonial rule. In its shift in emphasis away from interpretations of literary myths to a scientific analysis of behavior, anthropology also produced a decidedly more secular view of sacred kingship. ${ }^{15}$ E. E. Evans-Pritchard's study of the Shilluk of Sudan exemplifies this turn. ${ }^{16}$ For Evans-Pritchard, in an important departure from Frazer, it was kingship and not the king that was universally sacred:

In my view kingship everywhere and at all times has been in some degree a sacred office. Rex est mixta persona cum sacerdote. This is because a king symbolises a whole society and must not be identified with any part of it. He must be in the society and yet stand outside it and this is only possible if his office is raised to a mystical plane. It is the kingship, and not the king who is divine. ${ }^{17}$

Evans-Pritchard stripped sacred kings of their transcendent authority by arguing that the essential purpose of a king was not to govern or make law. Instead, the king's role was fundamentally performative: "The king of the Shilluk reigns but does not govern. . . . Both his function and status are primarily of a ritual order."18 For Evans-Pritchard, this ceremonial function also explained why African polities were unstable and prone to violence. As such, sacred kingship was a form of governance that was necessarily in decay. It is worth adding that in his emphasis on ceremony, Evans-Pritchard paved the path for work such as Clifford Geertz's Negara or Nicholas Dirks's The Hollow Crown and eventually, Moin's. ${ }^{19}$

This recapitulation of Frazer and Evans-Pritchard reminds us, as Gillian Feeley-Harnik has underscored, that "arguments about divine kingship" were really "arguments about the course of human history, the transformation of superstition into logic." ${ }^{20}$ They were evolutionary narratives. Sacred kingship was a primitive form of government that was eventually superseded by the nationstate. For both Frazer and Evans-Pritchard, it only existed elsewhere, either in the ancient past or the far-away colonies. In other words, studies of sacred kingship satisfied a certain imperial vision of the world. But the effect of these early studies, Feeley-Harnik also explains, was "profoundly equivocal." ${ }^{21}$ In the wake

15. Feeley-Harnik, "Issues in Divine Kingship," 275.

16. E. E. Evans-Pritchard, "The Divine Kingship of the Shilluk of the Nilotic Sudan: The Frazer Lecture, 1948," Hau: Journal of Ethnographic Theory 1, no. 1 (2011), 407-422.

17. Ibid., 420.

18. Ibid., 413.

19. Clifford Geertz, Negara: The Theatre State in Nineteenth-Century Bali (Princeton: Princeton University Press, 1980); and Nicholas B. Dirks, The Hollow Crown: Ethnohistory of an Indian Kingdom (Ann Arbor: University of Michigan Press, 1993).

20. Feeley-Harnik, "Issues in Divine Kingship," 307.

21. Ibid., 273. 
of World War I and the crisis of liberal democracies that followed, a narrative of historical progress, of the triumph of reason over superstition, held less purchase upon the imagination of Europeans. Political myths seemed to resurface in the present, infusing the discussion of kingship with danger and urgency. In this context, the bright lines that distinguished sacred kingship from sovereignty, past from present, and religion from politics blurred. Indeed, Frazer concluded his twelve volumes precisely where he began, back in the Grove of Nemi. Rather than confidently asserting progress, his final lines express melancholy and confusion, a sense that we have only substituted one set of political myths for another: "The roi est mort, vive le roi! Ave Maria!" In this way, Frazer anticipated Wittgenstein's savage criticism of The Golden Bough. ${ }^{22}$

Perhaps no figure exemplifies the equivocal mood of this postwar period more than Ernst Hartwig Kantorowicz. During his career, Kantorowicz wrote two monumental books, separated from each other by thirty years, that present two profoundly different perspectives on sacred kingship. In 1927, he published Kaiser Friedrich der Zweite, a biography of the Holy Roman Emperor, Frederick II. ${ }^{23}$ In this remarkable and voluminous tome, which was written without any footnotes, Kantorowicz emphasized the messianic quality of the medieval German ruler, who united political and religious authority in one figure, who crowned himself at the navel of the world, Jerusalem. Throughout the book, which focused on the rites, performances, occult sciences, and literary production of the court, Frederick appears as both Christ and Antichrist, an orthodox and heterodox figure, a lawmaker and lawbreaker at once. Kantorowicz did not hide his political intent in writing the book. In the face of the humiliations of the Weimar Republic, its territorial losses and economic bondage, he saw Germany's only hope for the restoration of its empire, the renovatio imperii Romanorum, in the figure of an exceptional ruler, a divine-like emperor, a true sovereign, whom no one can oppose but God himself. The book made Kantorowicz a celebrity in Germany, and no less than Göring, Goebbels, and Hitler lauded the work as a celebration of German national spirit. ${ }^{24}$

In his portrait of Frederick, Kantorowicz was deeply influenced not only by the Romantic mysticism of the poet guru Stefan George but also by the Nazi jurist and Catholic conservative Carl Schmitt. Like Bodin, Schmitt advocated for sovereignty in a moment of political crisis but reversed the poles of his predecessor. Schmitt believed that a liberal faith in secularism and constitutionalism was flawed. Law alone, he claimed, was insufficient. In Politische Theologie, he claimed that the nation-state could never supersede religion because "[a]ll significant concepts of the modern theory of the state are secularized theological concepts." ${ }^{25}$ In short, he argued that politics derives from religion, by which he

22. See, for instance, B. J. Coman, "Frazer, Wittgenstein and the Savage Mind," Quadrant 48, no. 6 (2004), 14-19; Ludwig Wittgenstein, Remarks on Frazer's Golden Bough, transl. A. C. Miles [1979] (Atlantic Highlands, NJ: Humanities Press International, 1991).

23. Ernst H. Kantorowicz, Kaiser Friedrich der Zweite (Berlin: G. Bondi, 1927).

24. Martin A. Ruehl, “'In This Time Without Emperors': The Politics of Ernst Kantorowicz's Kaiser Friedrich der Zweite Reconsidered," Journal of the Warburg and Courtauld Institutes 63 (2000), 188-189.

25. Carl Schmitt, Political Theology: Four Chapters on the Concept of Sovereignty (Chicago: University of Chicago Press, 2005), 36. 
meant a nonrational, spontaneous, and transcendental foundation. Invoking the medieval legal tradition princeps legibus solutus est, the prince is free from the law, Schmitt argued that a sovereign power that creates and maintains the law cannot be included within the law. Sovereignty stands before and outside of the law, and the sovereign is a stranger to the law. He is fundamentally an exception to the order he creates. The failure to recognize this fact, the absence of a true sovereign, explained Germany's weakness. As such, Schmitt had called for a return to an idealized synthesis of politics and theology, which he associated with the Catholic Middle Ages.

For his part, Kantorowicz, a German Jew, did not see the full significance of the brown shirts, who marched in the name of these ideas. He remained hopeful that the Nazis would restore the imperial glories of the past: "Today, the historian is quite frequently aware that the rites, chants and customs of the Middle Ages [Frederick II] unearthed, along with medieval ideologies, are becoming a reality again." ${ }^{26} \mathrm{He}$ waited and wavered before finally quitting Germany in 1939, several years after Hitler came to power.

In 1957, Kantorowicz published The King's Two Bodies. ${ }^{27}$ In form and content, Kantorowicz's two works are strikingly different. The King's Two Bodies is heavily laden with footnotes. A formerly prophetic tone is replaced by an obscurantist one: "Only hesitatingly and rarely did the author find it necessary to draw conclusions or indicate how the various topics discussed in these pages should be ... [integrated] with each other." ${ }^{28}$ Kantorowicz also disavowed that his new work had any political intent:

It would go much too far, however, to assume that the author felt tempted to investigate the emergence of some of the idols of modern political religions merely on account of the horrifying experience of our own time, in which whole nations, the largest and the smallest, fall prey to the weirdest dogmas and in which political theologisms become genuine obsessions defying in many cases the rudiments of human and political reason. ${ }^{29}$

Kantorowicz had abandoned, it seemed, romantic history to join the sober current of new historicism.

Despite this disavowal, The King's Two Bodies can be read as an apology for Kaiser Friedrich der Zweite, an effort to situate Frederick within a longer historical narrative, and an attack on Schmitt's political theology, his theory of the sacred origin of politics. Employing liturgical works, polemics, royal images, and rituals, Kantorowicz set out to explain the medieval and early modern concept of the king's two bodies, the body politic and body natural. Fundamentally, his aim was to overturn the assertion that politics depended upon and emerged from religion, that kingship was sacred:

Taken all by itself, this transference of definitions from one sphere to another, from theology to law, is anything but surprising or even remarkable. The quid pro quo method-the

26. From an unpublished version of his Laudes Regiae as cited in Ruehl, “"In This Time Without Emperors,"” 236.

27. Ernst H. Kantorowicz, The King's Two Bodies: A Study in Mediaeval Political Theology (Princeton: Princeton University Press, 1997).

28. Ibid., xxxvii.

29. Ibid., xviii. 
taking over of theological notions for defining the state-had been going on for many centuries, just as, vice versa, in the early centuries of the Christian era the imperial political terminology and imperial ceremonial had been adapted to the needs of the Church. ${ }^{30}$

He argued that just as secular Roman imperial metaphors informed the early Christological debates - the challenge of explaining Christ's humanity and divinity - so Christian metaphors were in turn later adapted to answer political questions. For English lawyers of the Crown, the doctrine of the incarnated body of Christ allowed them to imagine the idea of the king's two bodies, one for the office and the other for the person. If one potential of this history was the rise of absolutism and the cult of personality, then the other was political constitutionalism and secular humanism. In short, for Kantorowicz, this history of borrowing, a quid pro quo, did not reveal the religious foundation of politics but rather reminded Europeans of the serendipitous and fragile journey that brought them to political rationalism. The book ends with a passionate defense of reason over religion, of constitutionalism over imperialism. In short, The King's Two Bodies was an argument for secular modernity and against the threat of political theology. Kantorowicz had abandoned the sacralization of politics for its secularization.

In order to make sense of these competing theories of kingship from Frazer to Kantorowicz, one must see them as part of the broader debates about politics and religion that gripped Europe during the "crisis of culture" that followed World War I. On the one hand, liberal positivists committed to the ideals of the Enlightenment, reason and toleration, dismissed religion as mere ideology, as a set of empty rituals designed to manipulate credulous masses. On the other hand, Romantic conservatives rejected what they called the "shallow Enlightenment" as cold and excessive rationalism. Adapting theories of race, biology, and psychology, conservatives argued that religion was necessary for the function of community and society. In short, across Europe, liberals hoped to cure modernity of the ills of religion, and conservatives hoped to cure religion of the ills of modernity. These two essential positions were hopelessly locked, and as the case of Kantorowicz demonstrates, these debates were not otiose but rather the fault lines of war.

The ferocity and insolubility of these debates to the present, I would suggest, derives not from their disagreement but rather from a more fundamental but littlerecognized agreement between them..$^{31}$ If liberals saw religion as an irrational and unnecessary delusion that impeded individual freedom, and conservatives saw it as a passionate and spontaneous force that binds community, then what is striking - but little commented upon - is that they both agreed about the nature of religion and its relationship to politics. ${ }^{32}$ Both saw religion as a set of nonrational, transcendent, and premodern beliefs that served social cohesion. Both found the meaning of religion in its worldly function. Both understood religion as distinct

30. Ibid., 19.

31. I develop the argument below more fully in The Mercenary Mediterranean: Sovereignty, Religion, and Violence in the Medieval Crown of Aragon (Chicago: University of Chicago Press, 2016).

32. See, for instance, Jonathan Sheehan, "Sacrifice before the Secular," Representations 105, no. 1 (2009), 19. 
from and opposed to politics. In other words, they shared an essentially secular understanding of religion. Where they differ, however, is merely upon the value of that religion: one saw religion as an impediment and the other as a fundament. Thus, rather than opposing empirical, philosophical, or methodological positions, they are better understood as competing moral narratives.

The inner solidarity between these approaches is readily apparent in Kantorowicz. Across his works, despite his changing values, Kantorowicz held the same essential picture of sovereignty. Whether located in an emperor, a constitution, or an ideal like humanism, a sovereign power than binds a community is always exceptional, numinous, spontaneous, and ultimately, a precious fiction. Although they emphasize the dark and monstrous potential of sovereignty, more recent works by Giorgio Agamben, Luc de Heusch, and Marhsall Sahlins continue to rely upon the same view as Schmitt and Kantorowicz. ${ }^{33}$ If decidedly more optimistic and restrained, Moin also shares this essential outlook.

If this intellectual history, so deeply entwined with imperialism and war, casts a shadow on studies on sovereignty and sacred kingship, then the rigid distinction between religion and politics that underwrites it also offers a path toward breaking the deadlock. As Philippe Buc has argued, both liberal and conservative accounts of religion were heirs of the theological tradition. ${ }^{34}$ Both perspectives developed as a response to the nineteenth-century Protestant-liberal synthesis - the attempt to reconcile religious belief with the liberal Enlightenment by marking religion and politics, belief and reason, as compatible because they were also radically different. Whereas religion was grounded in man's subjective and nonrational experience of a transcendent divinity, politics was the public and rational unfolding of God's worldly plan. This was religion purified of the dangers of ritual and the embarrassments of real presence. ${ }^{35}$ But if the goal was to safeguard religious belief against charges of superstition or false consciousness, the synthesis did not succeed. Secular liberals drew upon this theological distinction to dismiss religion as pure unreason. Catholic conservatives, like Schmitt, rejected the Protestant solution and called for the reintegration of religion with politics and belief with ritual. Significantly, as Robert Nisbet argued decades ago, these conservative arguments profoundly influenced the modern sociological tradition. ${ }^{36}$ While exchanging an emphasis on veracity for function, Durkheim's theory of the sacred, Weber's charisma, and Turner's theory of ritual were grounded upon the idea that spontaneous and irrational beliefs had the ability to

33. Giorgio Agamben, Homo Sacer: Sovereign Power and Bare Life, transl. Daniel Heller-Roazen (Stanford: Stanford University Press, 1998); Luc de Heusch, The Drunken King, or the Origin of the State (Bloomington: Indiana University Press, 1982); and Marshall Sahlins, "The Stranger-King or, Elementary Forms of the Politics of Life," Indonesia and the Malay World 36, no. 105 (2008), 177 199, esp. 185: "Admittedly, my notions of the so-called 'supernatural' rest on simple-minded and old-fashioned premises. I take the rather positivist and Malinowskian view that people must in reality depend for their existence on external conditions not of their own making - hence and whence the spirits." See also Marshall Sahlins, "Twin-born with Greatness: The Dual Kingship of Sparta," Hau: Journal of Ethnographic Theory 1, no. 1 (2011), 63-101.

34. Philippe Buc, Dangers of Ritual: Between Early Medieval Texts and Social Scientific Theory (Princeton: Princeton University Press, 2001), 194.

35. Robert A. Orsi, History and Presence (Cambridge, MA: Harvard University Press, 2016).

36. Robert A. Nisbet, The Sociological Tradition (New York: Basic Books, 1966), 221-263. 
create community, that the fundamental and necessary purpose of religious ritual was to bind individuals into a collective. The ambition of the social sciences was to unmask religion as a mere social construction. ${ }^{37}$ From here, it is a short journey to Evans-Pritchard.

This view of religion also leads us back to early modern world, to the world of Jean Bodin. In their assaults upon Catholics as well as Jews, Muslims, and other non-Christians, Protestant theologians drew sharp distinctions between beliefs and rituals, between modern and primitive religion. True religions oriented men toward inward belief, whereas false beliefs and ceremonies were the product of ideology or superstition. Think, for instance, of Zwingli's disgust for Catholic practices. It is not, however, correct to say, as some do, that "religion" was a Protestant invention. Medieval Catholics made the same distinction when they looked at China and the Islamic world with admiration for their political genius but horror for their false religious beliefs. It can be found in Islamic and Jewish theology. It can be found in the writings of Augustine, the Gnostics, Paul, and even the Stoics. The point is simply this: the radical distinction between politics and religion upon which theories of sacred kingship and sovereignty have relied is a polemical one. These terms belong to a history of disputation not description. So, what other choices do we have?

In a recent book, I examined the competing claims of Christian and Islamic rulers in the thirteenth-century western Mediterranean to universal and imperial authority over Muslims, Christians, and Jews. ${ }^{38}$ Like the Safavids and Mughals, these rulers also saw themselves as exceptions to and above the law. They too appeared like stranger-kings. Iberian rulers even called themselves "sovereign." Some, like Frederick II of Sicily, have been dismissed as heretics; others, like Alfonso X of Castile, have been embraced as enlightened and tolerant, and yet others, like 'Abd al-Mu'min, the Almohad Caliph, have been dismissed as intolerant oppressors. Yet they all seemed to share the same script. They borrowed one another's curious court rituals, bureaucratic practices, occult sciences, literature, architectural styles, and even one another's subjects, as slaves, in order to assert and perform their claims to divinely inspired and universal authority. Rather than expressing something fundamental about kingship or sovereignty, I argued that this surge in sovereign claims reflected particular social, material, and theological circumstances. In particular, it reflected two overlapping juridical traditions: on the one hand, the political messianism of the Almohads, who imagined the caliph as a lamp of reason and a divinely guided lawmaker, and on the other hand, the revival of Roman law at royal courts, in which the authority of an emperor derived from the God-given and exclusive right to make the law. I traced the genealogy of these ideas back to the 'Abbasids and the Byzantines, who, in turn, competed to assert themselves as the heirs of the Roman and Sassanian Empires. Although distinct in important ways, this history both resonates with The Millennial Sovereign and has connections to it that are worthy of comparative study.

37. For a critique of this perspective from within religious studies, see Jonathan Z. Smith, "A Twice-Told Tale: The History of the History of Religion's History," in Relating Religion: Essays in the Study of Religion (Chicago: University of Chicago Press, 2004).

38. Fancy, The Mercenary Mediterranean. 
Nevertheless, I diverge from Moin in arguing that sovereignty falls short of a total explanation of political authority. At least in the thirteenth-century Mediterranean, these claims to sovereignty were just that, claims. They masked a context of competition not only among these rulers but also within their realms by royal pretenders, churchmen, religious lawyers, noblemen, and others, who not only rejected but also challenged these rulers. I contend that these claims to universal authority were meaningful only in this context of competition. What is more, the practice of royal power in the Iberian Peninsula and North Africa diverged widely from its rhetoric and performance. In other words, not everyone shared the same script or played the same game. To be sure, the social, intellectual, and material circumstances of the Mughal court were different. But even if Mughal sacral kingship was never contested in the same fashion as Mediterranean kingship, the divergence between them is significant. It reminds us to cut theories of sacred kingship and sovereignty down to size and to grant them less power over our analysis. ${ }^{39}$ It reminds us that this particular intellectual inheritance, which is freighted with anxious polemic, is anything but inalienable.

\section{University of Michigan}

39. A point made recently by David Graeber, "The Divine Kingship of the Shilluk: On Violence, Utopia, and the Human Condition, or, Elements for an Archaeology of Sovereignty," Hau: Journal of Ethnographic Theory 1, no. 1 (2011), 55: "The will to sovereignty is not, as reactionaries always want us to believe, something inherent in the nature of human desire-as if the desire for autonomy was always also necessarily the desire to dominate and destroy. Neither however does the historical emergence of forms of sovereignty mark some kind of remarkable intellectual or organizational breakthrough. Actually, taken simply as an idea, sovereignty, like monotheism, is an extraordinarily simple concept that almost anyone could have thought of. The problem is it is not simply an idea: it is better seen, I think, as proclivity, a tendency of interpretation immanent in certain sorts of social and material circumstances, but one which nonetheless can be, and often is, resisted." 